\title{
Analisis Risk Asset Portfolio Berbasis Reward to Variability Pada Saham Syariah di Indonesia Menggunakan Nonlinear Programming
}

\author{
Noor Saif Muhammad Mussafi ${ }^{1}$ \\ Program Studi Matematika UIN Sunan Kalijaga ${ }^{1}$, noor.mussafi@ uin-suka.ac.id ${ }^{1}$
}

DOI:https://doi.org/10.15642/mantik.2017.3.2.57-64

\begin{abstract}
Abstrak
Penelitian ini berupaya menganalisis pengembangan metode optimasi saham syariah menggunakan Nonlinier Programming dalam rangka memberikan alternatif portofolio optimal sebagai referensi dalam meningkatkan kualitas pasar modal syariah di Indonesia. Desain penelitian yang digunakan adalah deskriptif kualitatif dengan menyajikan suatu data histori saham syariah dalam periode tertentu yang dianalisis dan dimodelkan untuk kemudian dicari solusinya. Data dalam penelitian ini adalah informasi harga saham syariah yang tergabung dalam Jakarta Islamic Index (JII). Data yang terseleksi dengan analisis Reward to Variability (RVAL) kemudian dianalisis menggunakan teori-teori dalam matematika keuangan dan dikembangkan menggunakan quadratic programming. Hasil penelitian ini adalah rumusan langkah sistematis memaksimalkan tingkat keuntungan dan meminimalkan tingkat risiko investasi saham syariah yang tergabung dalam JII pada domain waktu Januari 2015-Desember 2016. Penelitian ini juga menyimpulkan bahwa dengan metode tersebut dapat diketahui proporsi dana yang dapat diinvestasikan pada lima emiten terbaik. Pada sampel yang diambil, untuk tingkat keuntungan yang diharapkan sebesar 5,5\% hingga 7,5\%, maka seorang investor disarankan untuk menanamkan sahamnya berturut-berturut kepada AKRA, ICBP, PTPP, TLKM, dan WSKT rata-rata sebesar $29,74 \% ; 13,42 \% ; 18,14 \% ; 29,58 \%$; dan $9,1 \%$ dengan risiko antara $0.028301593 \%$ hingga $0.029386615 \%$.
\end{abstract}

Kata kunci: Saham syariah; Quadratic proramming; Tingkat risiko; Tingkat keuntungan; RVAL.

\begin{abstract}
This research seeks to analyze the development of syariah stock optimization method using Nonlinear Programming in order to provide an optimal portfolio as a reference in improving the quality of syariah capital market in Indonesia. The research design used is descriptive qualitative by presenting a Shariah stock history data within a certain period that is analyzed and modeled for later sought solving. The data in this research is the stock price information syariah incorporated in the Jakarta Islamic Index (JII). Selected data with Reward to Variability (RVAL) were then analyzed using theories in financial mathematics and developed using quadratic programming. The result of this research is systematic step formulation to maximize profit level and minimize risk level of syariah share investment incorporated in JII in January 2015-December 2016 time domain. This research also concludes that by this method can be known the proportion of funds that can be invested in five best issuers. In the sample taken, for the expected profit level of 5.5\% to $7.5 \%$, then an investor is advised to embed its shares consecutively to AKRA, ICBP, PTPP, TLKM and WSKT on average of $29.74 \%$ ; $13.42 \% ; 18.14 \%$; $29.58 \%$; And $9.1 \%$ with risk between $0.028301593 \%$ to $0.029386615 \%$.
\end{abstract}

Keywords: Syariah stock; Quadratic proramming; Risk; Return; RVAL. 


\section{Pendahuluan}

Investasi menurut Islam merupakan kegiatan muamalah yang sangat dianjurkan, karena dengan berinvestasi harta atau aset yang dimiliki seseorang menjadi produktif sehingga mampu mendatangkan manfaat bagi orang lain, dengan syarat penerapannya berpedoman pada prinsipprinsip syariah. Bahkan dalam Al Quran (Surat Yusuf: 47-48) telah dijelaskan bagaimana seorang Nabi Yusuf 'Alaihissalam telah melakukan terobosan luar biasa dalam berinvestasi melalui tiga tahapan yaitu penanaman berturut-turut, penyimpanan sebagian hasil tanaman (bahanpangan) untuk mengantisipasi masa paceklik, dan penghematan dalam konsumsi [11].

Semenjak PT. Bursa Efek Jakarta (BEJ) menerbitkan daftar reksadana, saham, dan obligasi syariah dalam Jakarta Islamic Index (JII) pada tahun 2000 yang ditindaklanjuti dengan nota kesepahaman antara BAPEPAM dengan Dewan Syariah Nasional - Majelis Ulama Indonesia (DSN-MUI) tentang prinsip pasar modal syariah, pasar modal syariah mengalami perkembangan cukup signifikan. Analis Danareksa Sekuritas [9] mengatakan kinerja indeks saham syariah mengungguli kinerja Indeks Harga Gabungan (IHSG) pada awal hingga pertengahan tahun 2016. Ada tiga faktor penyebab peningkatan kinerja saham syariah yaitu (1) saham-saham syariah biasanya termasuk good corporate governance (GCG) artinya memiliki kualitas faktor pengawasan yang jauh lebih baik dibandingkan saham konvensional, (2) dari sisi sektor, saham syariah banyak terdiri dari sektor konsumer dan infrastruktur yang notabene mendorong kinerja indeks, dan (3) investor syariah biasanya membeli saham untuk investasi, bukan semata-mata trading sehingga kenaikannya lebih stabil.

Seperti sifat investasi pada umumnya, terdapat 2 (dua) hal mendasar yang selalu melekat yaitu tingkat keuntungan (return) dan risiko (risk) yang akan dihadapi. Keuntungan dan risiko mempunyai hubungan yang kuat dan linear, yaitu jika risiko tinggi maka keuntungan juga akan tinggi, atau sebaliknya [6]. Investasi saham pada pasar modal merupakan investasi yang memilki risiko tinggi sehingga jika tidak berhati-hati dapat memungkinkan terjadinya kebangkrutan. Untuk itu dalam upaya mencegah masalah tersebut perlu adanya manajemen risiko.

Salah satu cara dalam manajemen risiko adalah tidak menempatkan investasi hanya pada satu saham saja tetapi melakukan diversifikasi dengan membentuk portofolio saham. Dalam membentuk portofolio saham, pertanyaan terbuka dan signifikan bagi setiap investor adalah bagaimana menentukan proporsi dana yang diinvestasikan untuk setiap saham pada suatu portofolio, sehingga keuntungan yang dihasilkan semaksimal mungkin dan risiko yang diambil seminimal mungkin. Oleh karena itu, tujuan penelitian ini menganalisis portofolio berbasis reward to variability (RVAL) menggunakan prinsip Nonlinear Programming. Selanjutnya pendekatan tersebut diterapkan pada aset risiko saham syariah di Bursa Efek Indonesia (BEI).

\section{Pasar Modal Syariah di Indonesia}

Pada tanggal 3 Juli 2000, PT Bursa Efek Indonesia bekerjasama dengan PT Danareksa Invesment Management (DIM) meluncurkan indeks saham yang dibuat berdasarkan syariah Islam, yaitu Jakarta Islamic Index (JII). Indeks ini diharapkan menjadi tolak ukur kinerja sahamsaham yang berbasis syariah serta untuk lebih mengembangkan pasar modal syariah. JII terdiri atas 30 saham yang terpilih dari saham-saham yang sesuai dengan syariah Islam dan pemilihan sahamnya dilakukan oleh BAPPEPAM-LK bekerjasama dengan Dewan Syariah Nasional (DSN) melalui 2 tahap, yaitu seleksi syariah dan seleksi nilai volume transaksi [1]. Dalam proses transaksi investasi saham dipengaruhi salah satunya oleh BI Rate sebagai bank sentral. BI Rate adalah suku bunga kebijakan yang mencerminkan sikap atau stance kebijakan moneter yang ditetapkan oleh bank Indonesia dan diumumkan kepada publik.

\section{Matematika Keuangan}

Dalam matematika keuangan dikenal beberapa istilah penting diantaranya yaitu keuntungan, risiko, rataan aritmatik, rataan geometrik, variance, covariance, volatility, dan Reward to Variability (RVAL). Konsep dasar tersebut berkorelasi langsung dengan istilah- 
istilah dalam dunia keuangan khususnya bursa efek.

\subsection{Keuntungan dan Risiko}

Hal mendasar dalam keputusan investasi adalah tingkat keuntungan yang diharapkan dan risiko [12]. Keuntungan merupakan hasil (tingkat pengembalian) yang diperoleh sebagai akibat dari investasi yang dilakukan, secara matematis dapat digunakan pendekatan geometris [8]. Pendekatan ini menggunakan kaidah logaritma rasio harga dengan asumsi dividen $D_{t}$ adalah nol, secara matematis dinyatakan sebagai berikut:

$$
r_{t}=\ln \frac{I_{t}+D_{t}}{I_{t-1}}
$$

Risiko (risk) adalah tingkat ketidakpastian akan terjadinya sesuatu atau tidak terwujudnya suatu tujuan, pada kurun atau periode waktu tertentu [2]. Perhitungan risiko juga dapat dilakukan menggunakan standar deviasi [5] dengan formula:

$$
s=\sqrt{\frac{n \sum_{i=1}^{n} x_{i}^{2}-\left(\sum_{i=1}^{n} x_{i}\right)^{2}}{n(n-1)}}
$$

\subsection{Rataan Aritmatik, Rataan Geometrik, Variance, Covariance, dan Volatility}

Dari sekumpulan data emiten dapat dikalkulasi rataan aritmatik tingkat keuntungan $r_{i t}$ tiap aset $i$ pada periode $t$ menggunakan

$$
\bar{r}_{i}=\frac{1}{T} \sum_{t=1}^{T} r_{i t}
$$

Secara konsep rataan geometrik berbeda dengan rataan aritmatik [7]. Rataan geometrik merupakan rata-rata keuntungan tahunan yang bersifat konstan dan diaplikasikan pada tahun $t=0$ hingga $t=T-1$. Formula rataan geometrik $\mu_{i}$ adalah

$$
\mu_{i}=\left(\prod_{t=1}^{T}\left(1+r_{i t}\right)\right)^{\frac{1}{T}}-1
$$

Variance $\sigma^{2}$ pada variabel (berobot) berganda merupakan kombinasi linear dari covariance dengan bobot tiap aset $w_{i}$ dan nilai harapan pada tiap aset $X_{i}$ memiliki pola sebagai berikut:

$$
\begin{aligned}
& \sigma^{2}=\operatorname{var}\left(\sum_{i=1}^{n} w_{i} X_{i}\right) \\
& =\operatorname{cov}\left(\sum_{i=1}^{n} w_{i} X_{i}, \sum_{j=1}^{n} w_{j} X_{j}\right) \\
& =\sum_{i=1}^{n} \sum_{j=1}^{n} w_{i} w_{j} \operatorname{cov}\left(X_{i}, X_{j}\right) \\
& =\sum_{i=1}^{n} w_{i}^{2} \operatorname{var}\left(X_{i}\right) \\
& +2 \sum_{i=1}^{n} \sum_{j=i+1}^{n} w_{i} w_{j} \operatorname{cov}\left(X_{i}, X_{j}\right)
\end{aligned}
$$

Adapun covariance matrix dari dua sebarang aset pada periode $\mathrm{T}$, tingkat keuntungan $r_{i t}, r_{i t}$ dan rataan aritmatik $\bar{r}_{i}, \bar{r}_{j}$ dapat dinyatakan sebagai berikut:

$$
\operatorname{cov}\left(R_{i}, R_{j}\right)=\frac{1}{T} \sum_{t=1}^{T}\left(r_{i t}-\bar{r}_{i}\right)\left(r_{j t}-\bar{r}_{j}\right)
$$

Volatility merupakan perhitungan variasi harga instrumen keuangan berbasis waktu yang berkorelasi dengan standar deviasi. Volatility $\sigma$ tingkat keuntungan pada tiap aset $i$ secara matematis [4] dinyatakan sebagai

$$
\sigma_{i}=\sqrt{\operatorname{cov}\left(R_{i}, R_{j}\right)}
$$

\subsection{Reward to Variability (RVAL)}

Secara khusus kinerja portofolio dapat diukur dengan Sharpe Measure atau disebut dengan Reward to Variability (RVAL). Menurut [7], teknik ini diperkenalkan pertamakali oleh William F. Sharpe pada 1966 (perhatikan formula 8). Misal $\overline{T R_{p}}$ merupakan rata-rata return total portofolio dalam periode tertentu, $B I_{\text {rate merupakan aset bebas risiko yang }}$ ditetapkan Bank Indonesia, dan $\sigma$ adalah standard deviasi, maka 


$$
R V A L=\frac{\overline{T R_{p}}-B I_{\text {rate }}}{\sigma_{p}}
$$

\section{Teori Optimasi dan MATLAB}

Optimasi secara matematis berarti meminimalkan atau memaksimalkan fungsi tujuan dari beberapa variabel keputusan dengan kendala tertentu [10]. Permasalahan optimasi dalam penelitian ini dibatasi pada optimasi diskrit dengan batasan tertentu. Program kuadrat memungkinkan memiliki satu atau lebih kendala dalam bentuk persamaan ataupun pertidaksamaan [13]. Bentuk umum dari program kuadrat adalah:

$$
\begin{gathered}
\min _{x} \frac{1}{2} x^{T} Q x+c^{T} x \\
\text { s.s. } A x=b, C x \geq d, \quad x \geq \\
0
\end{gathered}
$$

Matriks $A, C \in \mathbb{R}^{m x n}$ dan tiga vektor $b \in$ $\mathbb{R}^{m}, d \in \mathbb{R}^{m}$, dan $c \in \mathbb{R}^{n}$ diketahui. Adapun $Q$ merupakan matriks simetris $\left(Q_{i j}=Q_{j i}\right)$ karena $x^{T} Q x=\frac{1}{2} x^{T}\left(Q+Q^{T}\right) x$. Tujuan akhir (9) adalah meminimalkan koefisien vektor $x$ pada fungsi tujuan kuadrat $\frac{1}{2} x^{T} Q x+c^{T} x$. Program Kuadrat dapat digunakan untuk meminimalkan risiko suatu saham yang diinvestasikan pada pasar modal dengan kendala jumlah dana yang diinvestasikan dengan acuan nilai covariance pada suatu data keuntungan [4].

Saat ini permasalahan optimasi tidak hanya dapat diselesaikan secara manual namun juga dapat diselesaikan menggunakan bantuan beberapa software, salah satunya adalah MATLAB. Portofolio optimal Markowitz MVO pada prinsipnya menggunakan model program kuadrat, yaitu meminimalkan fungsi kuadrat terhadap satu atau lebih fungsi kendala dalam bentuk persamaan ataupun pertidaksamaan.

Dalam optimization toolbox MATLAB [3], salah satu sintak yang dapat digunakan dalam menyelesaikan program kuadrat yaitu $x=$ quadprog $(Q, c, A, b$, Aeq, beq $) \quad$ dimana $Q, A$, dan $A e q$ adalah matriks sedangkan $c, b$, dan beq merupakan vektor. Sintak $x=$ quadprog $(Q, c, A, b$, Aeq, beq $)$ berarti vektor $x$ meminimalkan fungsi kuadrat $\frac{1}{2} x^{T} Q x+c^{T} x$ terhadap dua fungsi kendala yaitu pertidaksamaan $A x \leq b$ dan persamaan Aeq. $x=$ beq.

\section{Hasil dan Pembahasan}

Metode Optimasi Nonlinear Programming merupakan salah satu pendekatan manajemen portofolio untuk mendapatkan hasil optimal. Untuk melakukan analisis risk asset portfolio menggunakan metode nonlinear programming diperlukan beberapa langkah sistematis dalam ranah statistik dan pemodelan (lihat gambar 1).

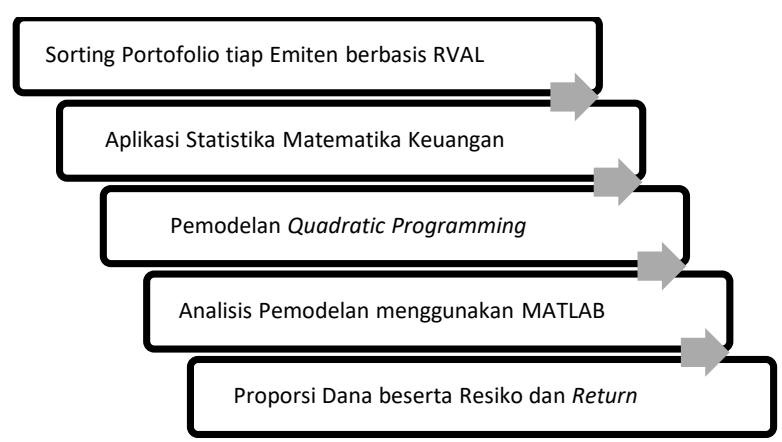

Gambar 1 Flowchart Penelitian

Investasi Syariah di pasar modal Indonesia identik dengan Jakarta Islamic Index (JII) yang terdiri dari 30 saham syariah yang tercatat di Bursa Efek Indonesia (BEI) sebagaimana terlihat pada tabel 1. Semua peserta yang tergabung dalam JII tersebut telah memenuhi kriteria syariah yang ditetapkan

\begin{tabular}{|c|c|c|}
\hline No. & $\begin{array}{c}\text { Kode } \\
\text { Saham }\end{array}$ & Nama Saham \\
\hline 1 & AALI & Astra Agro Lestari Tbk. \\
\hline 2 & ADHI & Adhi Karya Tbk. \\
\hline 3 & ADRO & Adaro Energy Tbk. \\
\hline 4 & AKRA & AKR Corporindo Tbk. \\
\hline 5 & ANTM & Aneka Tambang Tbk. \\
\hline 6 & ASII & Astra International Tbk. \\
\hline 7 & BSDE & Bumi Serpong Damai Tbk. \\
\hline 8 & ICBP & Indofood CBP Sukses Tbk. \\
\hline 9 & INCO & Vale Indonesia Tbk. \\
\hline 10 & INDF & Indofoof Sukses Makmur Tbk. \\
\hline 11 & INTP & Indocement Tunggal Prakasa Tbk. \\
\hline 12 & KLBF & Kalbe Farma Tbk. \\
\hline 13 & LPKR & Lippo Karawaci Tbk. \\
\hline 14 & LPPF & Semen Indonesia (Persero) Tbk. \\
\hline 15 & LSIP & London Sumatra Indonesia Tbk. \\
\hline 16 & MIKA & Mitra Keluarga Karyasehat Tbk. \\
\hline 17 & MYRX & Hanson Internasional Tbk. \\
\hline 18 & PGAS & Perusahaan Gas Negara Tbk. \\
\hline 19 & PTBA & Tambang Batubara Bukit Asam Tbk \\
\hline 20 & PTPP & Pembangunan Perumahan Tbk. \\
\hline 21 & PWON & Pakuwon Jati Tbk. \\
\hline
\end{tabular}
oleh PT. Danareksa Invesment Management (DIM).

Tabel 1. 30 Perusahaan Emiten Saham Syariah 


\begin{tabular}{ccl}
\hline $\mathbf{2 2}$ & SILO & Siloam International Hospital Tbk. \\
\hline $\mathbf{2 3}$ & SMGR & Semen Indonesia Tbk. \\
\hline $\mathbf{2 4}$ & SMRA & Summarecon Agung Tbk. \\
\hline $\mathbf{2 5}$ & SSMS & Sawit Sumbermas Sarana Tbk. \\
\hline $\mathbf{2 6}$ & TLKM & Telekomunikasi Indonesia Tbk. \\
\hline $\mathbf{2 7}$ & UNTR & United Tractors Tbk. \\
\hline $\mathbf{2 8}$ & UNVR & Unilever Indonesia Tbk. \\
\hline $\mathbf{2 9}$ & WIKA & Wijaya Karya Tbk. \\
\hline $\mathbf{3 0}$ & WSKT & Waskita Karya Tbk. \\
\hline
\end{tabular}

Pergerakan harga saham dari 30 perusahaan emiten saham syariah pada kurun waktu Januari 2015-Desember 2016 dapat diunduh pada [14].

Tabel 2. Rekapitulasi RVAL Berdasarkan Urutan Positif Terbesar

\begin{tabular}{ccccc}
\hline No & $\begin{array}{c}\text { Kode } \\
\text { Saham }\end{array}$ & Return & Resiko & RVAL \\
\hline 1 & TLKM & 0,000674409 & 0,016098664 & $-0,00105$ \\
\hline 2 & UNVR & 0,000360023 & 0,01839513 & $-0,00121$ \\
\hline 3 & AKRA & 0,000587106 & 0,019726625 & $-0,00129$ \\
\hline 4 & WSKT & 0,00117845 & 0,02000722 & $-0,0013$ \\
\hline 5 & ICBP & 0,000541993 & 0,019937375 & $-0,00131$ \\
\hline 6 & PTPP & 0,000225039 & 0,020120157 & $-0,00132$ \\
\hline 7 & ASII & 0,000228079 & 0,022562515 & $-0,00148$ \\
\hline 8 & INDF & 0,000126139 & 0,022676586 & $-0,00149$ \\
\hline 9 & UNTR & 0,000419695 & 0,026141486 & $-0,00171$ \\
\hline 10 & MYRX & 0,00047359 & 0,026700548 & $-0,00175$ \\
\hline 11 & PWON & $9,23604 \mathrm{E}-05$ & 0,026571898 & $-0,00175$ \\
\hline 12 & LPPF & $4,77805 \mathrm{E}-05$ & 0,027122928 & $-0,00179$ \\
\hline 13 & ANTM & $3,96577 \mathrm{E}-05$ & 0,030118297 & $-0,00199$ \\
\hline 14 & PTBA & $2,05109 \mathrm{E}-05$ & 0,030392115 & $-0,00201$ \\
\hline 15 & ADRO & 0,000996861 & 0,032972075 & $-0,00214$ \\
\hline
\end{tabular}

Selanjutnya dilakukan sorting portofolio harian tiap emiten saham syariah selama periode Januari 2015-Desember 2016 dengan mempertimbangkan risiko (standar deviasi), return (tingkat keuntungan) bernilai positif, dan analisis RVAL dengan $\mathrm{BI}$ rate $6,6 \%$ berturut-turut menggunakan formula (1), (2), dan (8) sehingga diperoleh data 15 emiten sebagaimana pada tabel
2 yang diurutkan berdasarkan nilai RVAL terbesar. Hal ini dilakukan karena semakin tinggi nilai RVAL maka akan semakin baik kinerja saham [7].

Bila ditinjau secara grafis (gambar 2), terdapat hubungan antara performa return dan risiko terhadap RVAL, yaitu pada 6 emiten dengan RVAL terbaik berturut-turut TLKM, UNVR, AKRA, WSKT, ICBP, dan PTPP. Dalam grafik tersebut (ditandai dengan pelabelan nama emiten) terlihat posisi keenam saham tersebut berada pada area kanan bawah yang berarti high return low risk.

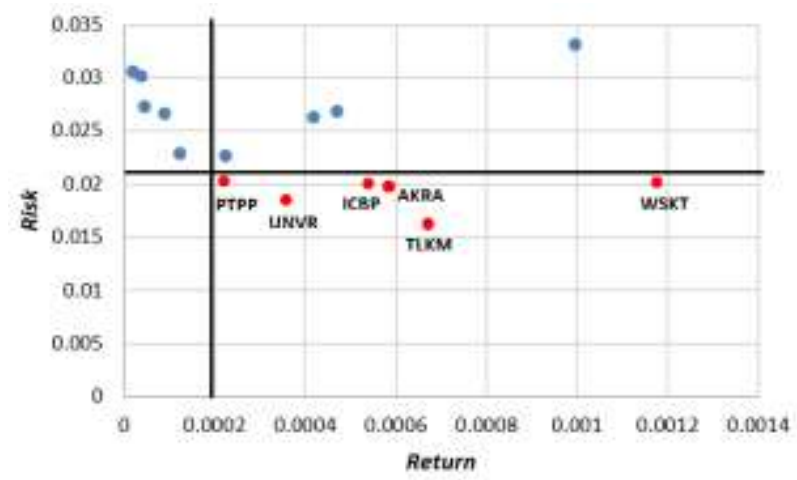

Gambar 2 Topologi 6 Emiten Dengan RVAL terbesar

Tabel 3 menunjukkan hasil kalkulasi rataan aritmatik tingkat keuntungan $r_{i t}$ tiap saham $i$ pada periode $t$ dan rataan geometrisnya (lihat (3) dan (4)). Kemudian menggunakan formula (5) dan (6) dapat ditentukan covariance matrix atau matriks yang unsur-unsurnya berupa variance dan covariance dari enam variabel/saham berturutturut yaitu AKRA, ICBP, PTPP, TLKM, UNVR, dan WSKT (Tabel 4).

Tabel 3. Rataan Aritmatik dan Rataan Geometris Rate of Return (6 saham terbaik)

\begin{tabular}{ccccccc}
\hline & AKRA & ICBP & PTPP & TLKM & UNVR & WSKT \\
\hline$\overline{r_{i}}$ & 0,000597715 & 0,00056 & 0,000227 & 0,000740614 & 0,004438108 & 0,001271307 \\
\hline$\mu_{i}$ & 0,000593798 & 0,000555 & 0,00022 & 0,000737094 & 0,004253044 & 0,001265167 \\
\hline
\end{tabular}

Tabel 4. Covariance Matrix 6 saham

\begin{tabular}{ccccccc}
\hline & AKRA & ICBP & PTPP & TLKM & UNVR & WSKT \\
\hline AKRA & 0,0000078429 & 0,0000017703 & $-0,0000002053$ & 0,0000005441 & $-0,0000051125$ & $-1,6838 \mathrm{E}-06$ \\
\hline ICBP & 0,0000017703 & 0,0000098097 & 0,0000036495 & 0,0000023484 & 0,0000067100 & $4,3967 \mathrm{E}-06$ \\
\hline PTPP & $-0,0000002053$ & 0,0000036495 & 0,0000125603 & $-0,0000007600$ & 0,0000052675 & $6,01781 \mathrm{E}-06$ \\
\hline
\end{tabular}


JURNAL MATEMATIKA "MANTIK"

Edisi: Oktober 2017. Vol. 03 No. 02

ISSN: 2527-3159

E-ISSN: 2527-3167

\begin{tabular}{ccccccc}
\hline TLKM & 0,0000005441 & 0,0000023484 & $-0,0000007600$ & 0,0000070373 & 0,0000106337 & $2,22524 \mathrm{E}-06$ \\
\hline UNVR & $-0,0000051125$ & 0,0000067100 & 0,0000052675 & 0,0000106337 & 0,0003723178 & $-4,4953 \mathrm{E}-06$ \\
\hline WSKT & $-1,68377 \mathrm{E}-06$ & $4,3967 \mathrm{E}-06$ & $6,01781 \mathrm{E}-06$ & $2,22524 \mathrm{E}-06$ & $-4,49528 \mathrm{E}-06$ & $1,2306 \mathrm{E}-05$ \\
\hline
\end{tabular}

Langkah berikutnya adalah pemodelan quadratic programming (program kuadrat) dalam konteks optimisasi portofolio dengan fungsi tujuan covariance matrix dan fungsi kendala rate of return. Misalkan variabel saham AKRA, ICBP,
PTPP, TLKM, UNVR, dan WSKT berturut-turut dinotasikan dengan $x_{A}, x_{B}, x_{C}, x_{D}, x_{E}$, dan $x_{F}$, maka dapat disusun pemodelan matematika berikut ini

$\min _{x_{A, B, C, D, E, F}}$

$0.0000078429 x_{A}^{2}+\left(2 \times 0.0000017703 x_{A} x_{B}\right)+\left(2 \times-0.0000002053 x_{A} x_{C}\right)$

$+\left(2 \times 0.0000005441 x_{A} x_{D}\right)+\left(2 \times-0.0000051125 x_{A} x_{E}\right)+\left(2 \times-1.68377 E-06 x_{A} x_{F}\right)$

$+0.0000098097 x_{B}^{2}+\left(2 \times 0.0000036495 x_{B} x_{C}\right)+\left(2 \times 0.0000023484 x_{B} x_{D}\right)+$

$\left(2 \times 0.0000067100 x_{B} x_{E}\right)+\left(2 \times 4.3967 E-06 x_{B} x_{F}\right)+0.0000125603 x_{C}^{2}+$

$+\left(2 \times-0.00000076 x_{C} x_{D}\right)+\left(2 \times 0.0000052675 x_{C} x_{E}\right)+\left(2 \times 6.01781 E-06 x_{C} x_{F}\right)+$

$0.0000070373 x_{D}^{2}+\left(2 \times 0.0000106337 x_{D} x_{E}\right)+\left(2 \times 2.22524 E-06 x_{D} x_{F}\right)+$

$0.0003723178 x_{E}^{2}+\left(2 \times-4.49528 E-06 x_{E} x_{F}\right)+1.2306 E-05 x_{F}^{2}$

\section{sedemikian sehingga}

$0.000597715 x_{A}+0.000560385 x_{B}+0.000226514 x_{C}+0.000740614 x_{D}+$ $0.004438108 x_{E}+0.001271307 x_{F} \geq R$

$x_{A}+x_{B}+x_{C}+x_{D}+x_{E}+x_{F}=1$

$x_{A}, x_{B}, x_{C}, x_{D}, x_{E}, x_{F} \geq 0$

Solusi dari program kuadrat (10) yang selanjutnya disebut sebagai portofolio efisien diperoleh dengan menentukan nilai return investasi $R$ pada interval $0,055 \leq R \leq 0,075$ dengan kenaikan 0,0025 . Untuk menemukan solusi program kuadrat tersebut dapat digunakan software MATLAB versi R2010a [3]. Hal tersebut dilakukan dengan memasukkan variabel $Q, f, A, b, A e q, b e q$ dan diikuti dengan sintak program kuadrat

$x=$ quadprog$(Q, f, A, b$, Aeq, beq $)$.

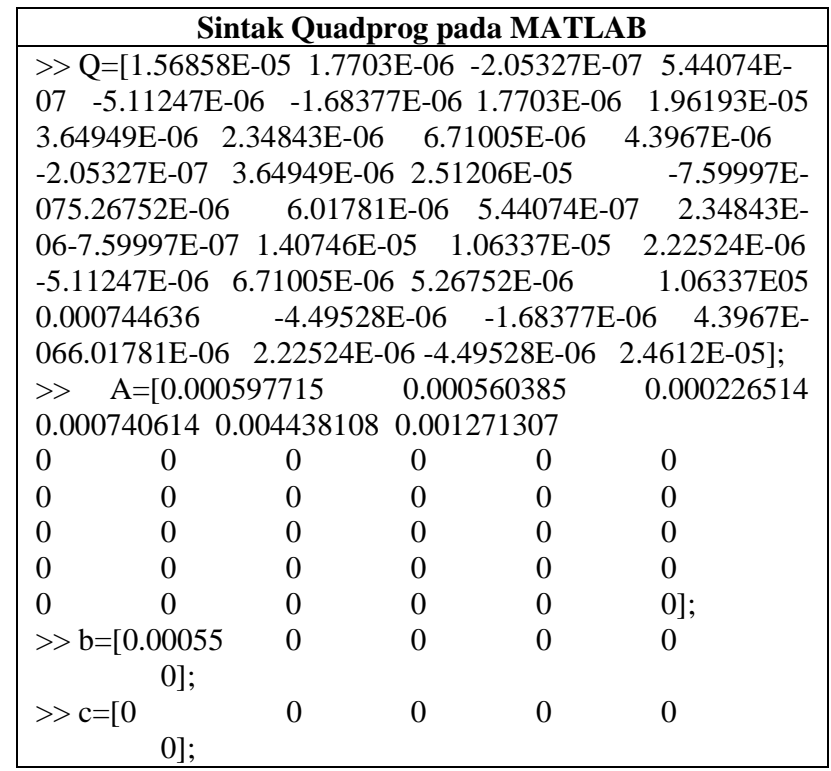

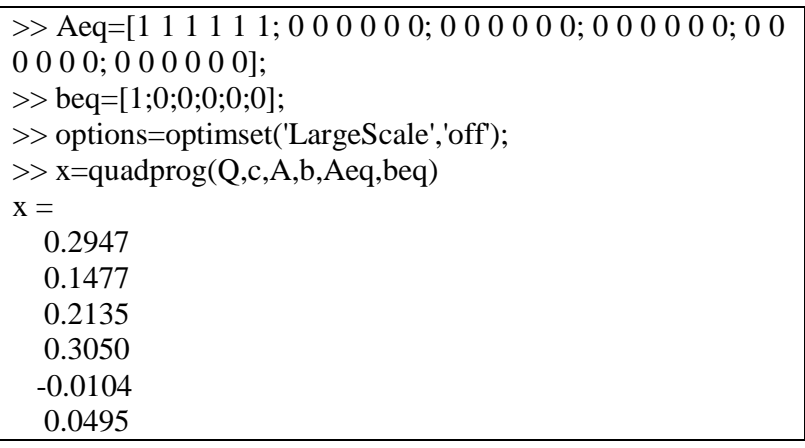

Hasil pemrograman pada MATLAB tersebut, utamanya pada nilai $x$, menunjukkan proporsi atau bobot masing-masing dana yang akan diinvestasikan dalam prosen. Diantara keenam saham tersebut ada satu saham yang memiliki bobot negatif -0,0104 ($1,04 \%$ ) yaitu saham UNVR. Dengan demikian perlu dilakukan perhitungan ulang optimasi pada portofolio dengan menghilangkan saham berbobot negatif, sehingga diperoleh portofolio baru dengan 5 (lima) saham berturut-turut AKRA, ICBP, PTPP, TLKM, dan WSKT. Dengan cara yang sama seperti pada analisis optimasi pada 6 saham, maka dilakukan identifikasi rataan aritmatik, rataan geometris rate of return, covariance matrix tiap saham, dan pemodelan program kuadrat baru dengan 5 variabel. Output dari pemrograman MATLAB terhadap model program kuadrat yang baru dapat disajikan dalam tabel 5 yang menunjukkan proporsi dana yang diinvestasikan 
(prosen) pada kelima saham syariah terpilih yaitu AKRA, ICBP, PTPP, TLKM, dan WSKT.

Di samping itu, dengan dengan menentukan nilai return investasi $R$ pada interval $0,055 \leq R \leq 0,075$ dan menggunakan formula (5) dapat dihitung pula variance dari masing-masing proporsi saham dengan mempertimbangkan nilai covariance (lihat tabel 5).

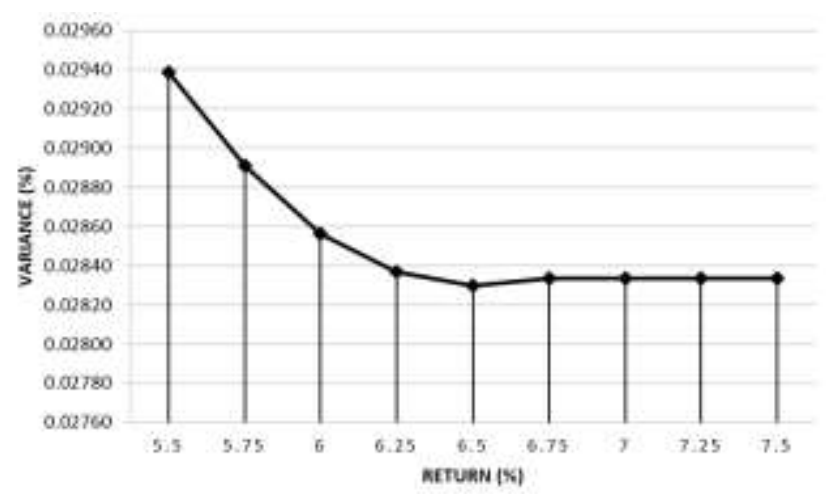

\section{Gambar 3 Grafik Rasio Antara Variance dan Return}

Variance pada tabel di atas menunjukkan tingkat risiko sedangkan $R$ adalah tingkat keuntungan. Pada umumnya tiap perubahan tingkat keuntungan menghasilkan proporsi saham yang berbeda, namun dalam kasus ini diperoleh tren proporsi yang sama atau konstan setelah mencapai interval $0,0675 \leq$ $R \leq 0,075$ (lihat gambar 3).

Tabel 5. Rekapitulasi Proporsi Tiap Saham (\%) Dengan R Dan Variance Tertentu

\begin{tabular}{ccccccc}
\hline $\mathbf{R}$ & AKRA & ICBP & PTPP & TLKM & WSKT & Variance \\
\hline 5,5 & 29,82 & 15,49 & 24,3 & 29,48 & 0,91 & 0,029386615 \\
\hline 5,75 & 29,79 & 14,84 & 22,35 & 29,51 & 3,51 & 0,028909367 \\
\hline 6 & 29,77 & 14,18 & 20,4 & 29,54 & 6,1 & 0,02856281 \\
\hline 6,25 & 29,75 & 13,53 & 18,45 & 29,58 & 8,7 & 0,028371985 \\
\hline 6,5 & 29,72 & 12,87 & 16,51 & 29,61 & 11,29 & 0,028301593 \\
\hline 6,75 & 29,71 & 12,48 & 15,33 & 29,63 & 12,86 & 0,028335619 \\
\hline 7 & 29,71 & 12,48 & 15,33 & 29,63 & 12,86 & 0,028335619 \\
\hline 7,25 & 29,71 & 12,48 & 15,33 & 29,63 & 12,86 & 0,028335619 \\
\hline 7,5 & 29,71 & 12,48 & 15,33 & 29,63 & 12,86 & 0,028335619 \\
\hline
\end{tabular}

Baik tabel 5 maupun gambar 3 memberikan informasi kepada calon investor dalam berinvestasi di saham syariah JII. Sebagai gambaran jika calon investor menghendaki tingkat keuntungan mencapai $6,75 \%$ maka proporsi dana (dalam prosen) yang dianjurkan, berdasarkan analisis nonlinier programming tersebut, untuk diinvestasikan kepada lima emiten saham syariah AKRA, ICBP, PTPP, TLKM, dan WSKT berturut-turut adalah $29,71 \%$, $12,48 \%, 15,33 \%, 29,63 \%$, dan $12,86 \%$. Adapun tingkat risiko yang akan ditanggung oleh investor tersebut adalah 0,028335619\%. Sehingga secara umum tren proporsi dana tertinggi direkomendasikan diberikan kepada AKRA sedangkan proporsi dana terendah diberikan kepada ICBP atau WSKT. Grafik di atas juga mencerminkan aspek umum investasi yang menyatakan high risk high return.

\section{Kesimpulan}

Proses seleksi portofolio saham syariah optimal dapat dilakukan dengan menghubungkan return-risiko dengan analisis RVAL. Saham atau aset terpilih selanjutnya dapat dianalisis menggunakan pemodelan program kuadrat untuk menghasilkan bobot atau proporsi dana sebagai rekomendasi bagi para calon investor saham syariah.

\section{Ucapan Terimakasih}

Penulis mengucapkan terimaksih kepada Lembaga Penelitian dan Pengabdian Masyarakat (LPPM) UIN Sunan Kalijaga atas skema pendanaan hibah penelitian rintisan pada tahun 2017. Tidak lupa juga ucapan terimakasih kepada Ketua Program Studi Matematika atas dukungan 
kegiatan penelitian ini dan Pak Mohammad Farhan Qudratullah atas diskusi kajian statistik terutama terkait dengan risk analysis.

\section{Referensi}

[1] Ayub, M., Understanding Islamic Finance: $A-Z$ Keuangan Islam, Jakarta: PT, Gramedia Pustaka Utama (2009).

[2] Batuparan D.S., 2000, BEI NEWS: Mengapa Risk Management? Edisi 4, Jakarta: Bursa Efek Indonesia (BEI).

[3] Brandimarte P., Numerical Methods in Finance and Economics : a MATLAB-based introduction, Edisi kedua, John Wiley and Sons Inc,, Hoboken, New Jersey (2006).

[4] Cornuejols G., and Tuetuencue R., Optimization Methods in Finance, Cambridge University Press (2007).

[5] David Ruppert, Statistics and Finance: An Introduction, Springer-Verlag New York, LLC (2004).

[6] Fahmi I., dan Hadi Y.I., Teori Portofolio dan Analisis Investasi, Teori dan Soal Jawab, Bandung: Penerbit Alfabeta (2009).

[7] Jogiyanto H,, 2013, Teori Portofolio dan Analisis Investasi, Cetakan Ketiga, BPFE Yogyakarta (2013).

[8] Jorion P., Value at Risk : The New Benchmark for Managing Financial Risk, McGraw-Hill, New York (2002).

[9] Lucky Bayu Purnomo, diunduh dari http://investasi,kontan,co,id/news/indekssaham-syariah-mengungguli-ihsg pada tanggal 1 Juni 2017.

[10] Mussafi, Optimisasi Portofolio Risiko Menggunakan Model Markowitz MVO, Jurnal AdMathEdu, ISSN: 2088-687X, Vol. 1 No. 1, FKIP UAD Yogyakarta (2011).

[11] Shihab M. Quraish, Tafsir Al-Misbah: Pesan, Kesan dan Keserasian Al-Qur'an, Vol. 6, Jakarta: Lentera Hati (2002).

[12] Tandelilin, E., Portofolio dan Investasi: Teori dan Aplikasi, Yogyakarta: Penerbit Kanisius (2010).

[13] Wolsey L.,A., Integer Programming, John Wiley and Sons, New York (1988).

[14]__, Harga Saham Bursa Efek Indonesia yang tergabung dalam Jakarta Islamic Index, diambil dari https://finance,yahoo,com/ pada tanggal $1 \mathrm{Juli}$ 2017. 